\title{
Sciendo
}

\section{European Union and Russia: international relations evolution}

\author{
Alessandro Figus \\ International Institute of Management IMI-Nova, Moldova \\ e-mail: vicerector.int.iminova@gmail.com
}

DOI: $10.2478 /$ gssfj-2020-0016

\begin{abstract}
Today the relationship between Russia and the today EU-28 (today EU-27) members of the European Union is essential and very strategically important; this issue is bound to become more urgent as the two draws closer together over the next decades. In this paper, we discuss this and the Russian Federation's role in the Ukraine conflict that has seriously affected EU-Russia relations. The EU and Russia have a long record of cooperation on issues of bilateral and international concern in several fields, from climate change to drug and buman trafficking, but also the organized crime, terrorism, and non-proliferation. In particular, Europe, the "old traditional Europe", acquires special weight for Russia in the context of the cooling down of relations between Russia and the United States. We will discuss gas, oil, and energy, but we can see that the solution can be only economic, and the oil and agriculture sectors could help do just that. "Business is business".
\end{abstract}

Keywords: international relations, Russia, European Union

\section{Introduction}

After the dissolution of the Soviet Union and its replacement by the Russian Federation, a number of opportunities have opened up for the European Union in the East. The relationship that Russia and Europe are asymmetrical, where the EU dominates the agenda and sets preferences.

The European Union encourages everyone to reform that economy towards a capitalist model, while Russia wants to regain an important role in the structuring of the new architecture of post-war and post-Cold War Europe, which since 1994 with the Partnership and Cooperation Agreement (PCA) changes precisely the institutional framework for EU-Russia relations.

However, negotiations have been problematic both because of Russian demands for negotiation of greater conditions in the economic field and rejection of the conditionality policy of the agreements. Second, because the European Union was not willing to do so in order to meet Russian demands. When these demands were given in part, it was because if certain demands of President Yeltsin and his government were not met, the reformists could have suffered political turmoil that would have blocked the difficult Russian transition.

The relations between this Russia and the EU were based on strong cooperation, but always in a disharmonious way, that is with an extremely Eurocentric idea also because Russia has experienced, especially before Putin took office, periods of great 
political instability with an economy in full recession and adapting to the change of the system. An example of this is the deep crisis of 1998 which confirmed its weakness (Pinder J. and Shishkov Y.V. 2002).

In this context, the European question and the Russian question are intertwined, and a whole series of events that have changed the relations between Russia and the European Union, including also the process of globalization and all those tragic events due to the growth of terrorist phenomena.

\section{The importance of EU-Russia relations}

The relationship between Russia and the European Union is of fundamental importance, but we cannot forget that it is enormously complex and difficult. The European Union has developed and must above all extend a policy towards Russia that is feasible, this is an ambitious and at the same time unavoidable project.

Also, relations with Russia, which are actually at a standstill at the moment, must look beyond the strenuous history that has marked them, forget personalism, old rusts, old doubts and look to new visions of bilateral agreements. The EU should treat Russia for what it is: a very important strategic partner, and try to make it progressively closer to the system of rules and values that today the European project represents.

Beyond bilateral diplomacy and the pressure that leaders - especially the German and French ones - have exerted in recent years on Putin, on the Ukrainian issue, on the Belarusian issue, first on the Georgian issue and the Syrian one, Putin does not want to hear about a UN intervention; the meetings were framed in the geostrategic shift from the Atlantic to the Pacific in which the Eurasian country wants to play an important role. This is the central point and has well-defined historical reasons (Figus, Ukrainian System, 2016).

The European crisis also has its deep roots in the rise of emerging countries and, in particular, Asia. The United States has also been affected by this change and the Atlantic axis has lost its ability to influence the world. The debate over the future role of NATO is one of the real consequences of this loss, as is the diminished influence of the EU in global terms. Russia looks to China, which is its first customer and with which it recently signed trade and industrial agreements for 5.5 billion euros. But aside from their good relations, there are also traditional and ancestral differences, and China's emerging influence in Central Asian countries contributes to Russian fears about its eastern neighbor and advises building bridges with Europe, which among other things depends on Russian energy sources.

Russia, it is true, has two souls: the European and the Asian, but more than threequarters of the Russian population lives in Europe. They are more European than Asian because their history and culture indicate this. As much as geostrategic change forces Moscow to build bridges with Asia, it does not want to turn its back on Europe. It has never done so, not even in its most egocentric historical moments. It will not do so now either because it does not favor it. On the contrary, Moscow now has the opportunity to act as a bridge between the European Union and the countries of the Far East, which gives it importance and influence in both areas, its two souls (Barbé E., 2000). 
Europe, for its part, is not interested in having Russia on the sidelines, and the Cold War proved it. Neither the Berlin Wall, nor the powerful ideological differences, not even the nuclear threats that were the basis of the status quo in the 1960s and 1970s, succeeded in breaking Russia's European vocation, nor the European will for an understanding with the areas of influence of the so-called Soviet bloc.

Now, once those enormous difficulties have been overcome, this understanding is not only possible but advisable. There are differences, of course, and perplexities to overcome between the two macro-regions. The meetings mainly between the French and Germans and Putin have been a good opportunity to continue to advance in this direction and to consolidate and deepen relations between Europe and Russia, an opportunity to consolidate the European leadership that in fact, the European Union is trying to exercise. However, Putin should not miss the opportunity to push this relationship forward and make it a fundamental building block for the future.

\section{Evolution of international relations between Russia and European Union}

Even after the tragic events of terrorism in Europe, I have on the table the question of whether or not the European Union wants to be a serious political player in a rapidly changing world. Today, to open the debate about the relationship between Russia and the EU-28 members of the European Union it is central and very important; this issue is bound to become more urgent as the two draws closer together over the next decades.

In reality, since the collapse of the Soviet Union, and the application of the Central and Eastern European states to join the European Union, the problem related to the Union enlargement with an unknowable Russia, stands exposed in a new form.

To understand the history of the relationship between Russia and the European Union, we need to get to the root of things and go back to 2004 when the European Union finalized one of the most important and ambitious decisions of its history; the expansion into the Central and Eastern European countries admitting eight new members: The Czech Republic, Hungary, Poland, Slovakia, Slovenia, and the three Baltic countries, Estonia, Latvia, and Lithuania. Russia has since become the new neighbor of the European Union and has been actively changing the geopolitics of the region. The EU and Russia were bound to be neighbors because of Russian influence (before the Soviet Union) and as active members of the European Union, a new geopolitical system, and a new strategy they created vision.

The European Union needs to devise a geopolitical strategy based on where its territorial interests lie and, in this case, it was imperative for the relations of Russia and the European Union was seen as of primary importance (Figus, 2019). This is because Russia plays an integral part in Europe; not only because of cultural and historical traditions but also because Russia heavily participates in key European security problems, which cannot be resolved without its participation.

More than twenty years after the Cold War, Europe now faces an increase of complex threats and challenges, but to what extent is Russian-European potential being realized, and what challenges impede its further development? It is evident that Russia is a significant strategic partner for Europe in the trade cooperation field. A large bulk of Russian oil and gas is exported to European countries and Russian 
supplies cover around $20 \%$ of all European demands of imported oil, and this percentage will only continue to grow implacably.

Russia's energy cooperation with the EU has created strong interdependence between the two, but the Ukrainian crisis has affected the EU's Energy Security and it especially has had an impact of energy use on the competitiveness of the EU's economy.

In fact, the crisis has set a new charter of life for the European debate on the future of the European energy system (especially gas and petroleum), and the role that the external energy suppliers are to play in this new scenario. This has become more vital than to improve the import from the other extra EU importers (see the table and figures below).

\begin{tabular}{l|rr}
\hline Partner & Value (Share \%) & Net mass (Share \%) \\
\hline Russia & 38.9 & 37.5 \\
Norway & 33.8 & 37.2 \\
\hline Algeria & 15.6 & 14.1 \\
\hline Qatar & 5.8 & 5.9 \\
\hline Nigeria & 2.3 & 2.2 \\
Libya & 1.7 & 1.4 \\
\hline Others & 1.9 & 1.7 \\
\hline
\end{tabular}

Sources: Eurostat database (Comext) and Eurostat estimates

Table 1 - Extra-EU-28 (including the UK) imports of natural gas(liquefied, gaseous state), main trading partners (2016)

Extra-EU imports of natural gas from main trading partners, 2018 and first semester 2019 (share $(\%)$ of trade in value)

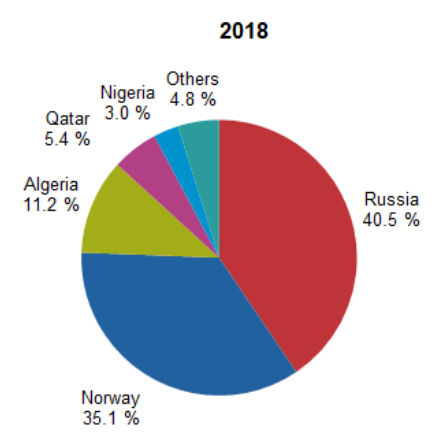

Source: Eurostat database (Comext) and Eurostat estimates

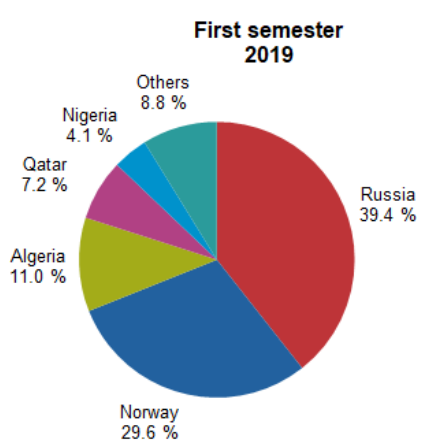

eurostat

Figure 1 - Extra-EU imports of natural gas from main trading partners, 2018 and first semester 2019 - Source: Eurostat database (Comext) and Eurostat estimates 


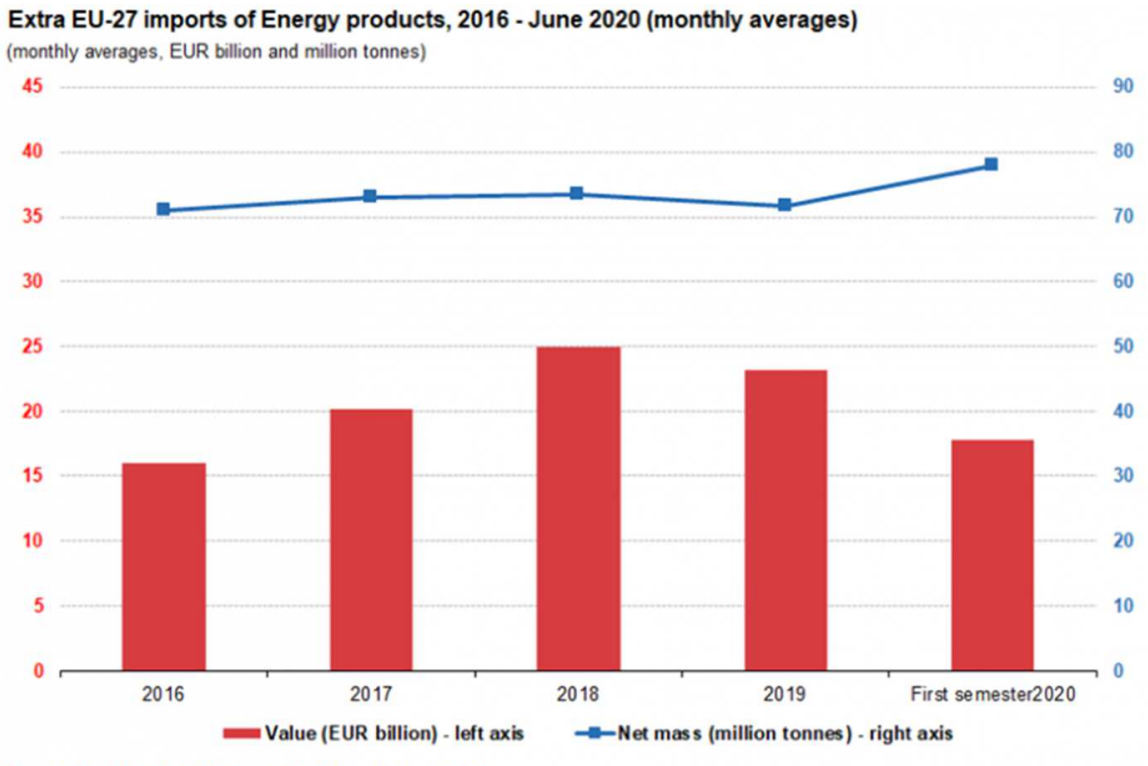

Source: Eurostat database (Comext) and Eurostat estimates

\section{eurostato}

Figure 2 - Extra-EU27 imports of energy products, 2016-June 2020 - Source: Eurostat database (Comext) and Eurostat estimates, 2020

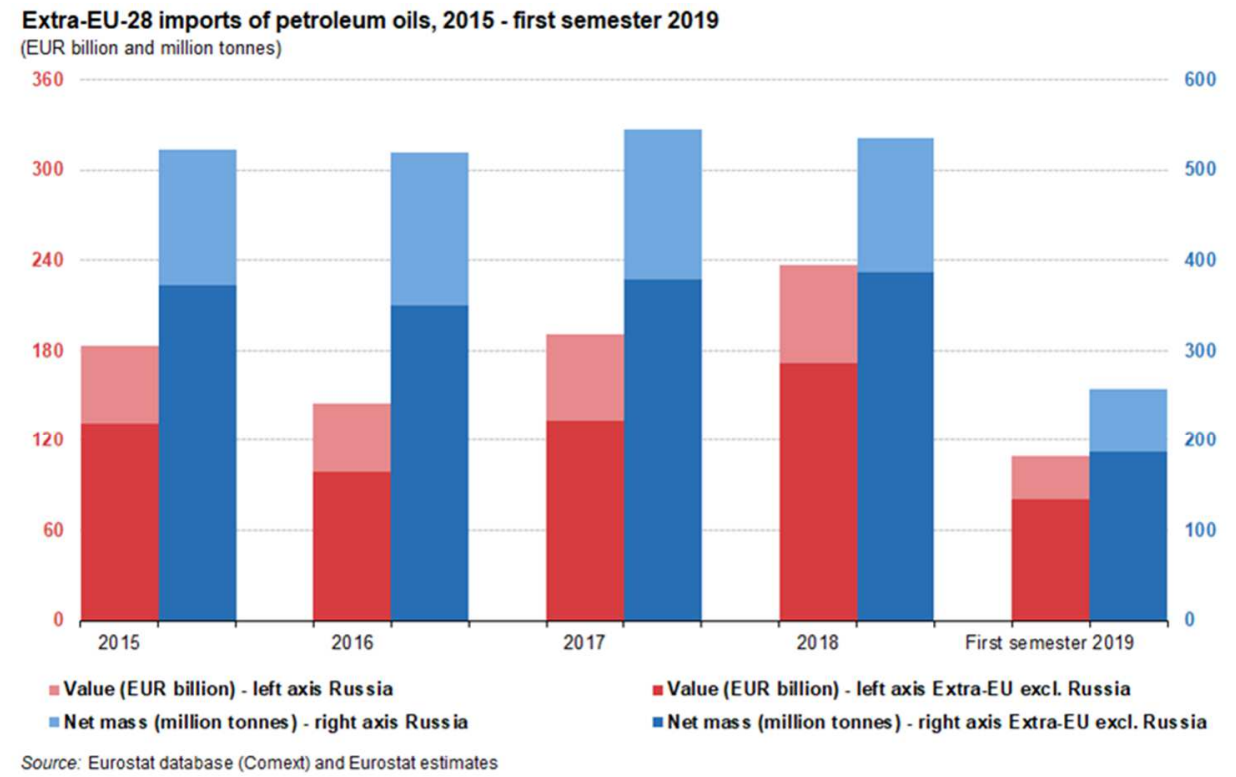

eurostati

Figure 3 - Extra EU28 imports of petroleum oils, 2015 - first semester 2019 - Source: Eurostat database (Comext) and Eurostat estimates 
As we reported, according to the latest available Eurostat data, primary production in the European Union amounted to just under 800 million tons of oil equivalent (TOE). Over the past decade, overall European production has fallen by around 15\% (Eurostat, 2019). The downward trend has been constant with the only exception being 2010, which saw a slight rebound from the 2008/2009 crash caused by the global economic and financial crisis. This negative tilt is attributable to both the depletion of available primary sources and the increased costs associated with the use of remaining reserves. This trend could presumably continue once we evaluate the data of the last year, i.e. the effects of the collapse of the oil price, which in the last 18 months has come close to the historic lows, i.e. at the exchange values recorded in 2004 .

At the moment no European country is self-sufficient from an energy point of view. Imports come mainly from Russia, historically the main supplier of crude oil and natural gas. In 2006 it also became the leading seller of solid fuels (with a share approaching 30\%) on the European market. In fact, one-third of the crude oil and natural gas consumed in Europe is coming from Russia. We know that Putin recently displayed that Europe is better off united than not when it faces problems beyond its borders. Today, the crisis in Ukraine appears distant, although it's only been a few months since clashes in the East of Ukraine, meanwhile it is important to remember. We are in front of a difficult tangle where a deepening of relations with Ukraine, Belarus, Moldova, the Southern Caucasus, and Central Asia can only last if Russia's interests in the European puzzle are taken into consideration. The relationship between Ukraine and the European Union could be oriented in the direction of a 'bridge' rather than a 'front' against Russia.

Still, in the difficult context of the partnership between the EU and Russia, it should not be forgotten that Russia plays an important role in the energy sector, especially after the recent agreement between China-Russia calling for the supply of Siberian natural gas to the Chinese. It underlines the significance of the energy threat to Europe if it does not comply with Russian expansion in the Caucasus, especially after Russia strengthened its ties with Iran (Figus, Politica Estera dell'Iran tra Occidente e crisi nucleare, 2013).

The United States' interest in Europe has since declined and Russia seeks to affirm her role as a "Superpower". Russia and China have common interests in Europe, and we are going into a new European cold winter where Russia has advantages and disadvantages over both parties. Europe was not only affected but also was put on alert by the recent economic and political crisis' in the relations between Russia, Ukraine and Belarus over the questions of the price for oil and gas (as before the years $2007 / 2009$ ) and especially in relation to the transportation problem through several oil pipelines such as Druzhba to the West.

The problem turns again around Germany, but not only. In fact, some other countries started to talk about the necessity of finding alternative sources of energy and suppliers of oil and gas. This resulted in a tarnished reputation for Russia, after the incident in Crimea and the Eastern part of Ukraine. The return of war to the European continent has come as an intense, if not delayed, the shock to the west. Just a year ago no one would have thought that it would come to this and that Europe would be struggling financially and economically, while caught off guard by Ukraine's turmoil and Russia's role in that. 
Now we have the immediate flashpoint in Eastern Ukraine, which the "Minsk declaration" announced by the leaders of Germany, France, Ukraine, and Russia was addressed. And then there is the long view, the wider picture to be grasped, and that concerns Europe's future and its long-term security.

Russia needs its economy to be transformed and it must embark on an innovative course of development. That is the reason why her excessive dependence on oil and gas is not considered to be good in perspective, even considering high world prices. Furthermore, proved resources of oil are enough to provide the country for only 20 or some more years. What heritage will we leave to future generations?

But still, there are more advantages than disadvantages to the cooperation between Russia and Europe. Europe covers more than $50 \%$ of all Russian external trade and this percentage is growing, taking into consideration the increasing demands of the European economy in energy resources. This process is also influenced by the enlargement of the European Union and the geographical nearness of Russia. Today, the European Union imports 50\% of consuming energy, but if the existing tendencies continue at this rate, they will not grow in the next years to come, because of the Ukraine Civil War; but actually, the European Union is Russia's largest trading partner. It is estimated that up to $75 \%$ of Foreign Direct Investment stocks in Russia come from EU Member States (including Cyprus), but this prediction will not be able to be met because of the embargo in response to the illegal annexation of Crimea and deliberate "destabilization" of a neighboring sovereign country. The EU has imposed restrictive measures against the Russian Federation.

Several factors have contributed to the ongoing Russia-EU crisis over the past 18 months with the political relations rapidly deteriorating. Starting from Russia's annexation of Crimea from Ukraine and followed by the crash of Malaysia Airlines passenger plane MH17, which has been widely blamed on Russia-backed rebels in east Ukraine.

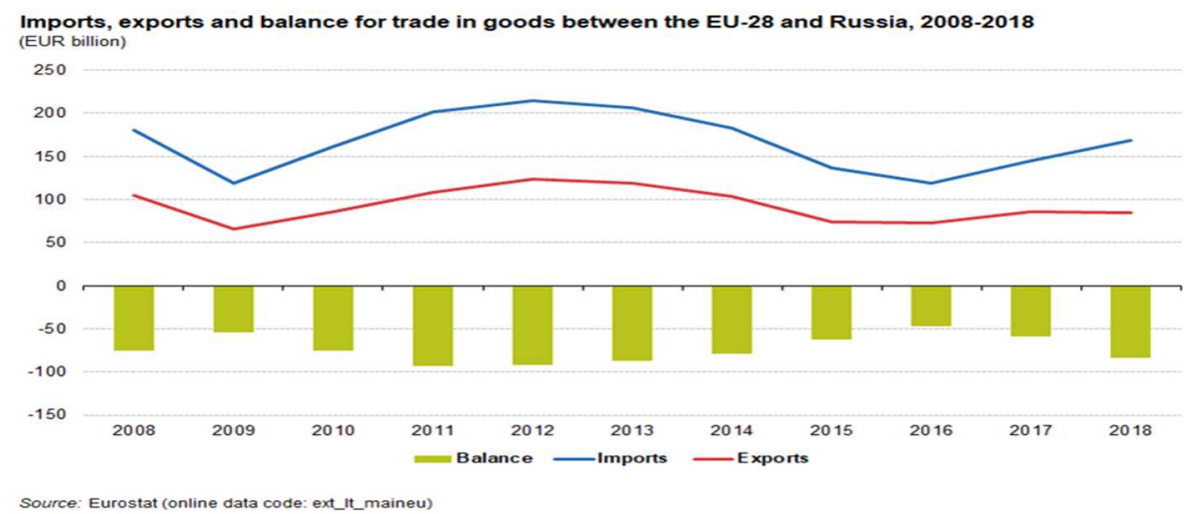

Source: Eurostat (online data code: ext_It_maineu)

Figure 4 - EU-Russia "trade in goods" balance - Source: Eurostat

The sanctions launched by both EU and Russia haven't completely dried-up trade, with exports from Russia to the European Union in the period 2008-2018, totaling 209 billion USD compared to around 225 billion USD a year earlier, which marked the highest export total over the previous years. 
In short, "business is business!"

European security is one of the more acute problems of present-day threats such as international terrorism, the spread of weapons of mass destruction, regional conflicts, and organized crimes.

In the struggle to fight terrorism, Russia actively cooperates with many countries and international organizations, NATO first and foremost. The key-tool in this sense is the Russia- NATO Council, which was created at the Russia summit in Rome on the 28th of May in 2002. Now, the structure of the Council consists of more than 20 working bodies including committees, working groups, and expert groups. Close cooperation in the struggle against terrorism is of great importance in the work of the Council. For example, a special working group on terrorism coordinated such documents as terroristic threat assessment of the peace-making forces in the Balkans and the threats from al-Qaeda, threat assessment of the country's members of the Council from Islamic terrorism, and radicalism in Central Asia, in the Middle East and Africa.

Of course, the activity of the Council is not always smooth and it faces problems and difficulties. It is not a secret that NATO's expansion to the East evokes alarm, although it is not reasonable enough amongst the Russian public opinion. According to the strategic concept of 1999, the Alliance exceeded the traditional zone of its responsibility, and it is not welcomed in Russia. Recently, NATO deviated from the principle of the supremacy of international law. Still, there are common threats and challenges, which call for joint and adequate answers and reactions on behalf of Russia and its partner.

NATO and the newly expanded European Union went on in a synchronized way; new members, as a rule, turned out to be the countries of Central and Eastern Europe, including ex-soviet republics. They play an important role in both organizations, continuously increasing their influence. In fact, the relations with these new NATO and European Union members assume more and more significance for Russia.

After the collapse of the Soviet Union, Russia left Central and Eastern Europe in a very rash and inconsiderate way, creating an impression that she did not even think of returning. Eventually, life settled down, repulsing her ex-allies, Russia did not benefit but lost. Friendly and good neighborly relations must be restored, especially as NATO and the European Union enlarge, with the inclusion in this process of Georgia, Moldova, and Ukraine. The economic part of Ukraine-European Union Association Agreement was signed on 27 June 2014 by the new President, Petro Poroshenko, the agreement commits Ukraine to economic, judicial, and financial reforms to converge its policies and legislation to those of the European Union, we don't know when will be operative and if Ukraine will be EU member state. In reality, the central point is that NATO respects Ukrainian President Petro Poroshenko's decision to sign a law on Ukraine's abandoning its non-aligned status, NATO officials said in December 2014. "Ukraine is an independent and sovereign state, and it can decide the direction of its own foreign policy," NATO officials said, commenting on the signing of the law by the former Ukrainian President Poroshenko during a press conference in 2014 (UNIAN's Brussels correspondent has been reported). 
It was not with Poroshenko but with Volodymyr Zelensky, who as a comedian with no political experience won in 2019 exactly against Poroshenko, there was an opportunity to improve cooperation with Russia. Medvedev declared that he had no illusions about Zelensky, claiming that Zelensky would also use the same rhetoric toward Russia that he used during his campaign.

Yet the elections "showed a clear demand for a new approach to solving problems with Ukraine," Medvedev said again. Zelenskyj has always had in his head, however, the peace process in which he would involve Russia in order to bring a rapid evolution of the war in the pro-Russian separatist east and for a cease-fire and release of Ukrainian prisoners in Russia. During the election campaign, one of the arguments of the outgoing president, Petro Poroshenko, had instead been to ensure that his rival was too inexperienced to deal with Vladimir Putin's Russia

The two countries have had tense relations since 2014 and the pro-European Maidan movement, forced then-President Viktor Yanukovich to flee to Moscow, Ukrainians took to the streets looking at the European Union. In fact, the crisis in Ukraine erupted in 2013, at a time when President Yanukovych halted preparations for an agreement on Ukraine's association with Europe in favor of another agreement that tied the country even more closely to Russia. This started the street protests known as Euromaidan. This move was followed by Russia's annexation of the Crimean peninsula in Ukraine and war in the east of the country with pro-Russian separatists that left nearly 13,000 dead. It seems clear that this has become a thorn in the side of the relationship between the European Union and Russia. On the one hand, we have a population that looks to Western Europe, but on the other hand, a population that objectively has Russian roots and is tied historically and culturally with Moscow, cannot be suddenly erased. Meanwhile, the conflict continues and has been the bloodiest in recent European history since the wars of the early 1990s in the former Yugoslavia.

In any case, Russia believes that NATO is destabilizing Northern Europe and the Baltic states, by holding military exercises there. Russia accuses NATO of encroaching on it by strengthening ties with Eastern European countries that used to be dominated by the Soviet Union. Today, Moscow has increasingly flexed its military ties with the West soured over Ukraine. For the Russians today, NATO is an organization, which is trying to destabilize the most suitable region in the world, Northern Europe, specifically the Baltic area. This is demonstrated by the fact that NATO transfers aircraft capable of carrying nuclear arms to the Baltic states which Russia perceives negatively.

NATO has stepped up joint exercise and offered additional reinforcement and a temporary rotation of forces in Eastern Europe to reassure members in the region who are worried by the crisis in Ukraine. Generals in Europe refer to this as mutual self-defense. The military policy is dangerously intertwined with economic policy, in particular energy policy, but each European state has its own vision and its own geopolitical perception, which stems from its history and geography.

Russia has to throw away the relics of imperial thinking and restore normal and constructive dialogue with the states, which compose its closest environment. Equally important for Russia is to stop portraying the role of an "elder brother" and display a spirit of friendliness to the countries of Central and Eastern Europe. Taking 
the former into account, it is possible to hope for a restoration of lost mutual confidence and to restore the position of Russia in this important region.

Russia and the countries of the European Union can treat regional cooperation as a reserve, which is still poorly used. For example, the Southern region of Russia is one of the areas that sets off this effective cooperation. In recent years, the administration contributed a lot to attract foreign investments into the economy of the region especially in the Agricultural sector, and for the establishment of close links with the business communities of Germany, Italy, France, Austria, Greece, UK, etc., etc.

A lot of publicity has been exemplified, to promote the South of Russia in Europe (Vienna, Paris, Rome, London, etc.). But, not surprisingly on this area, close to the Caucasus region, weighs a difficult geopolitical problem that has invested in recent past Georgia, a strong interest in joining the European Union, in particular involving South Ossetia. The same situation in Europe has in the Moldovan region of Transdniester (Figus, Le repubbliche post sovietiche: la Moldova, 1999).

All of these facts involve relations between Russia and the European Union but it often involves more relations between the Member States and not from the EU and Russian relationship as a whole. Sometimes the leaders play a bigger role than the States. While Europe suffers from leadership, Russia's Putin has been the engine of the new foreign policy strategy that has been used by his predecessors, first and foremost, Yeltsin. Foreign policy in Russia became more personalized than in Europe. In fact, in Europe, in principle we have 28 leaders, in Russia, we have only "the president", called a "new tsar". (This is normal; because in Russia, a cultural predisposition towards a strong political leadership exists. The comprehensible goal is to create a rebirth of the "Greater Russia", This impacts regional and international safety, sometimes even reflecting up to the European Union.

The local government puts attention and plays together with the other institutions for international cooperation. In fact, regional cooperation is also important for stimulating contacts between people and helps them to understand each other much better. It creates a realization, in a deeper way a commonality of interests for citizens of Russia and the European Union.

You can't hide that the relations between Russia and the European Union were at an all-time low in 2015, in fact, it was later challenged by the European Parliament in 2015 following the annexation of Crimea and war in an important Ukrainian region, the Donbas.

Europe, in particular, the "old traditional Europe", acquires special weight for Russia in the context of the cooling down of relations between Russia and the United States. Tensions always existed between these two powers, but while Russia has been strengthening its position in the world, they have become more distinct. Differences of opinion were displayed in different approaches to the events in Ukraine and in the Caucasus, in Eastern Europe, but also in Africa and in Central Asia, as well in the Middle East. Russians jealously watch as Americans are consolidating their positions in the oil fields of Azerbaijan and Kazakhstan, as well as their attempts to lead Ukraine and Georgia into NATO. These countries were once a part of the Russian Empire and USSR.

US offensive in CIS is defectively perceived by Russia because CIS (Commonwealth of Independent States), as the European Union, is another top priority for the foreign policy of Russia. CIS remains a centric Russian organization and to be a part of it, 
means to fall within the Russian Orbit, economically and geopolitically although the CIS is more related to Eurasia and the Middle East than Europe.

If someone predicts that the relations between Russia and the United States will hardly improve in the nearest future for the above-mentioned reasons, we can add on the disputes over Iraq and Iran especially in regards to the nuclear problem (Figus, 2013). It is easy to see the deepening of cooperation between a united Europe and the interests of Russia. Equally, the development of a strategic partnership with Russia meets the interests of the European Union (London, Authority of the House of Lords, 2015).

As global tensions increase over Georgia, Ukraine, Syria, and also Turkey, it's hard to imagine a future relationship between the European Union and Russia. Someone affirms that to be friends they have to separate the economic matters, from those of business.

The question of Europe's relationship with others often becomes central. Also, the comparison between Turkey and Russia after the shootdown of the Russian warplane on the Syrian border became a European issue. The incident marked a serious escalation in the Syrian conflict that is likely to further strain relations between Russia and the NATO alliance (Hallenberg J. and Karlsson H., 2006).

We are faced with a weave between the Turkish interests to reach the European Union and Russia's desire to re-establish good relations with the EU after the crisis in Ukraine. All this is a consequence of the rise of the power of Erdogan. In terms of foreign policy, Erdogan uncoordinated actions against Bashar Al-Assad's regime in Syria, which irritated Russia due to their strong business ties with Turkey, prior to the last tragic events. However, trade. remains important especially concerning energy supply. Russia has signed agreements with Turkey, and we must understand that they are also compelling political issues, this also directly involves the policy of the European Union.

We have spoken for a long time about gas, oil, and energy, but we can see that the solution can be only economic, and the oil and agriculture sectors could help do just that.

Almost impossible to believe, there is an abundance of politics in these businesses. The desire to reaffirm the leadership, in the European Union is static and seems torn between the United States and Russia (Pezard S., Radin A., Thomas S., Szayna T., Larrabee S., 2017), it plays a secondary role, but the most important thing is that lots of businesses are still cooperating and apparently for businesses, politics is a sort of secondary policy.

In short, once again; "business is business!".

\section{Conclusion}

China knows well it is ready to replace all who do not wish to sell to Russia. In fact, Putin looks to improve Russia's relationship with China amid rising tensions with Western Europe and with the West soured over the Ukrainian crisis. Putin needs to demonstrate that he has other centers of geopolitical power to turn on as well as to demonstrate to the domestic society, and to the international community that relations with the West are not as important and if the European Union doesn't want Russia's energy, then they will sell it to China. 
But the problem is not limited to the Chinese situation, there is also the problem related to Ukraine and Belarus. After the Ukrainian conflict and despite the economic ties between the two countries, it is difficult to foresee a normalization of relations in the short term. The objective could be to avoid the worst-case scenario, i.e. a deep rift. Instead, it becomes imperative to improve the lack of trust between Ukraine, Russia, and the European Union, in order to rebuild a spirit of trust between Brussels and Moscow (Authority of the House of Lords, 2015). The ties between Russia and the EU cannot be based only on economic foundations, also since in recent years, other nations have become established exporters, albeit with relatively modest shares of total imports: these are in particular Nigeria, Kazakhstan, and Azerbaijan, with regard to imports of crude oil, Qatar and Libya for imports of natural gas. Therefore, if both Russia and the EU want to re-establish normal relations, they must act with transparency and maintain a constant dialogue. An institutional relationship should be created that goes beyond the relationship with Russia, for example involving the Eurasian Union. It would be necessary to abandon the dynamics of competition in the region and move to the dynamics of cooperation among the various organizations as well.

As for the settlement of the Ukrainian conflict, then, it is also necessary today to be aware that the territory of Crimea will not return to Ukraine, everything now depends on the real ceasefire and the possible restoration of Ukrainian sovereignty in the Donbas despite the change of policy. Since the installation of the new Ukrainian president Volodymyr Zelensky, this path is not feasible in the short term and in any case only through a long diplomatic action, the only viable (Figus, Alberti, De Serio, 2020). Therefore, organizations such as OSCE should be used where the actors involved are, knowing the red lines that should not be crossed.

With progress in Russia-EU relations, a European security structure could be built. However, we cannot let ourselves be disappointed, the relationship between the EU and Russia will never be perfect. This European security structure could be defined as a balance, recognizing Russia's differences with the European Union (Makarychev A. S., 2009). Russia will not be integrated into institutions led by others and will maintain its great ambitions for power, as well as recognition by others of that status; for its part, the European Union will continue for the time being to proclaim itself a regulatory power.

Let us not forget that on top of the Ukrainian question there is the Belarusian issue. Essentially, the European Union is intervening in the crisis in Belarus. The first action is not far from the one taken on the issue of relations with Russia in Ukraine, i.e. it prepares sanctions. Also in Belarus, there is in fact an imposition of sanctions against the Lukashenko regime.

Putin has thus offered economic aid to Lukashenko, Moscow has taken over the sanctions that the Belarusian government has imposed as a reaction to the EU and has also placed Svetlana Tikhanovskaya, the leader of the Belarusian opposition and refugee in Lithuania on the list of persons wanted by its Ministry of the Interior. Meanwhile, the opposition leader continued her round of meetings with European political leaders, meeting with Macron and Angela Merkel. Following this round of talks, she called for Germany's mediation with Russia to resolve the crisis, and this is nothing new, history repeats itself once again. 
In fact, history teaches us that in the same way, the interests of Moscow and Brussels will never coincide, but will continue to have common interests and with a mutual understanding of both actors, the regulation of various fields, such as cyberspace, and the development of both actors, Russia towards a post-Putin regime, although this is a prospect that is not yet clear, and still seems far away.

The European Union is therefore positioned in a more autonomous position, it will be possible to move towards a European security structure whose main element is balanced and which will be fundamental to the new world order that is being formed.

\section{References}

Barbé E. (2000). Política exterior europea, Ariel, Barcelona.

Eskilinen H., Liikanen I., Scott J. (2013). The EU-Russia borderland: New contexts for regional co-operation, Routledge, London.

Figus A. (2013). Politica estera dell'Iran tra Occidente e crisi nucleare, Eurilink, Roma.

Figus A. (1999). Le repubbliche post sovietiche: la Moldova, Mattioli 1885.

Figus A. (2019). Sistema Europa. L'organizzazione politica dell'Unione Europea: il complesso cammino verso l'unione politica, Eurilink University Press.

Figus A. (2016). Sistema Ucraina, Eurilink University Press.

Figus A., Alberti, De Serio L. (2020). Ukraine a country in crisis between Europe, Russia, and a complex electoral process, Geopolitical, Social Security and Freedom Journal 3 (1). Gower J., Timmins G. (2010). The European Union, Russia and the shared neighbourhood, Routledge, London.

Hallenberg J., Karlsson H. (2006). Changing transatlantic security relations: Do the US, the EU and Russia form a new strategic triangle?, Routledge, London; New York.

Haukkala H. (2010). The EU-Russia strategic partnership: The limits of post-sovereignty in international relations, Routledge, London; New York.

House of Lords (2015). The EU and Russia: before and beyond the crisis in Ukraine, 6th Report of session 2014/2015, London, Authority of the House of Lords.

Pezard S., Radin A.,Thomas S., Szayna T., Larrabee S. (2017). European Relations with Russia, Rand Corporation.

Pinder J., Shishkov Y.V. (2002). The EU \& Russia: The promise of partnership, Federal Trust, London.

Makarychev, A. S. (2009). Russia and its 'new security architecture' in Europe: A critical examination of the concept, Brussels: Centre for European Policy Studies.

Stewart E. (2008). Capabilities and Coherence? The Evolution of European Union Conflict Prevention., in European Foreign Affairs Review 13: pp. 229-253.

Wolchik Sharon L., Curry J.L. (2011). Central and East European Politics: From Communism to Democracy, MD: Rowman \& Littlefield, Lanham. 